\title{
Et annet blodtrykk
}

Da de første antihypertensivene, tiazidene, kom på markedet i 1950-årene, forandret det forståelsen av hypertensjon. Tidligere var høyt blodtrykk en lidelse karakterisert ved sine symptomer, ikke ved den risiko det ga for sykdom i fremtiden. Behandling var først og fremst hvile og ro. Artikkelen som utdraget nedenfor er hentet fra (Tidsskr Nor Lægeforen 1932; 52: 65-74), er skrevet av leger ved Midtstuen sanatorium og beskriver deres forsøk med den såkalte Gerson-dietten. Dietten, signert den tyske legen Max Gerson (1881-1959), var opprinnelig utviklet for behandling av migrene. Etter hvert fikk den mer preg av å være et universallegemiddel. Dietten inneholdt mat og drikke laget av organisk dyrkede råvarer, mens neimat var salt, nesten alle animalske produkter samt tobakk, alkohol og legemidler. I Midtstuen sanatorium ble dietten brukt ikke bare mot hypertoni, men også ved nerve- og sinnslidelser, tuberkulose, nyrestein, akutt nefritt, hematuri og graviditet. Gerson-dietten fikk en relativt kortvarig karriere innenfor de skolemedisinske kretser, men er fremdeles populær innenfor alternativ medisin.

\section{«Gerson»-dietens anvendelse}

\section{En foreløpig meddelelse fra Midtstuen sanatorium, Holmenkollen}

\author{
(E Møinichen, H Frøshaug)
}

Ved Midstuen sanatorium har dieten vært benyttet på en rekke patienter fra begynnelsen av oktober 1930 . Vi mente, at det kunne ha en viss interesse å søke en foreløbig orientering om de virkninger som eventuelt kunde påvises, og har derfor gjennemgått vårt materiale i tiden 1 . oktober 1930 til 1. juni 1931 [...].

Vi må få blodtrykket til å falle, og til dels temmelig meget. Det kan skje på mange måter, for eksempel ved veneseksjon, ved medikamenter - ofte bare ved ro, ferie, sengeleie, regulert regime og noget innskrenket diet. Men vårt inntrykk er, at Gersondieten virker kraftigere enn de andre metoder. Blodtrykket faller raskere og fallet har tendens til å være varig - $\mathrm{i}$ allfall så lenge dieten blir gjennemført og så lenge vi har hatt anledning til å følge patienterne. Og det som for oss har vært det mest bemerkelsesverdige, er at tross det til dels svære og plutselige fall av blodtrykket har det subjektive befinnende som regel vært helt udmerket. Uttalelser som «jeg føler mig nu bedre enn på mangfoldige år», «føler mig 10 år yngre» og lignende har vært rett hyppige. På bakgrunn av en 25-årig erfaring med fysikalsk og dietetisk behandling av disse tilstander må det vel dog tillegges nogen betydning, at vi ved Midtstuen Sanatorium mener å se en vesentlig større nytte av Gersondieten enn av tidligere anvendte behandlingsmåter. I et par tilfeller, hvor der allerede lenge hadde vært anvendt saltfattig diet, medikamentell behandling og fysikalsk behandling, men tilstanden var stasjonær, har institueringen av Gersondiet bragt yderligere fall af blodtrykket sammen med økt velbefinnende og øket dyktighet (til å spasere og arbeide).

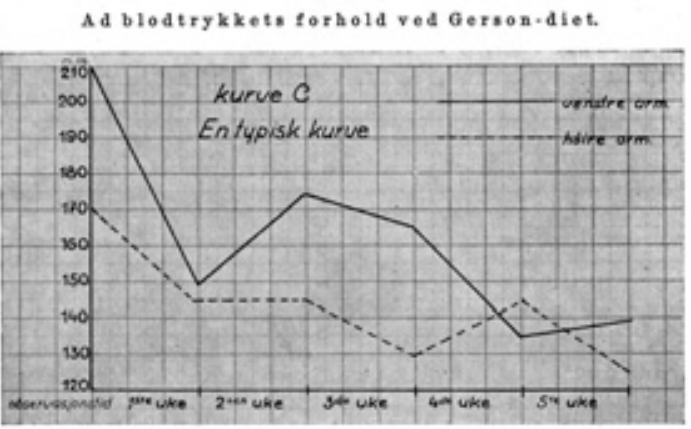

yru gardbruker H, 60 Ar. Patienten hadde de slate ar folt sig svimmel. Zfternt Gersom-diet var instituert folte hum sig tem. melig mart sobjektivt bedre. Kurvese viser blodtrykkets forhold under Kurven viser et temmelig typlak forhold ar bjodtrykket under es erson-diet. First faller trykket temmelig langt ned for sa $\mathbf{A}$, tige en smule, hrorps 